\title{
5
}

\section{Western and Eastern Ur-Topias: Communities and Nostalgia}

\author{
Anjan Sen ${ }^{1}$ and Asun López-Varela ${ }^{2}$ \\ ${ }^{1}$ National Tagore Scholar, \\ 2Universidad Complutense Madrid, \\ ${ }^{1}$ India \\ ${ }^{2}$ Spain
}

\section{Introduction}

In Western civilization, the prefix ' $U r^{\prime}$ is often used as metaphor to refer to a primitive, seminal, or prototypical example of an artistic representation, concept or idea. The associations of the word can be traced back to Sumerian sources and the origins of IndoEuropean civilization. Ur is considered by many to be the city of Ur-Kasdim mentioned in the Book of Genesis as the birthplace of the patriarch Abram (Abraham). The existence of cities can be traced back in antiquity to the important role of communities such as Memphis, Babylon, Thebes, Athens, Sparta, Mohenjodaro or Anuradhapura, among others. Rome was perhaps the first city to reach a population of one million around the time of Christ. Only in 1800 did London become the second city to reach this size. At that time only two percent of the world's population was urbanized.

Communities are not just defined in political and economic terms: cultural issues, perceptions, and foci contribute to give identity to the community, whether a village, a city, or a nation. Mirrors of cultural change, artistic representations offer insights into the way humans have transformed their living spaces. Works by artists, poets, novelists, visual artists, etc., helps unveil the distinctiveness in the way communities are viewed. The term mindscape, used to refer to human communities, refers to structures for thinking about human spaces built on conceptualisations of their physical landscape, whether urban or rural, and more recently virtual, as well as on their images as transported through cultural representation, memory, and imagination in different media formats. (see López-Varela \& Net 2009)

Mindscapes, whether cityscapes, landscapes or hyperspaces are, among other things, patterns of attitudes and ritualized behaviour; networks of human connections, of customs and traditions inscribed in certain practices and discourses, both internal and external. They suggest the "raw material for the symbols and collective memories of group communication" (Lynch 4), being "among other things, a state of mind, an order of morality, a pattern of attitudes and ritualized behaviour, a network of human connections, and a body of customs and traditions inscribed in certain practices and discourses." (Zhang 3-4) J. Hillis Miller has proposed that every narrative without exception, even the most abstract one, "traces out in its course an arrangement of places, dwellings, and rooms joined by paths and roads" (Miller 10), 
that is, it develops in a spatio-temporal framework. This framework exists through human involvement and, as Tom Henighan emphasises, even natural space is rendered from a human point of view and therefore must be understood as the expression of humans who occupy a certain place in and have a certain perspective on the real space of nature (Henighan 5).

In recent years, it is significant the number of studies that have focused on the cultural ideas of a community since practical outcomes of such an analysis may further our understanding of human dynamics such as 1) how the relationship between urban scenery may affect people's sense of belonging; 2) how after urban change and migratory movements, civic memory may still retain remembrances representative of the community; 3) how the dynamics of change whether environmental, technological, or cultural should ensure social justice and sustainable communities; and 4) how urban issues may affect conflict resolution between individual and communal demands such as mobility, equity, etc.

By 2050, the world population is expected to increase to a total of 9 billion, while the population living in urban areas is projected to grow by 2.9 billion, to a total of 6.3 billion. It is inevitable that this rapid increase of urban population will bring enormous economic, social and environmental pressures, resulting in a need for governments to take urgent measures. Against this backdrop, the United Nations Centre for Regional Development (UNCRD) is refocusing its work towards sustainable urban development. The UNU Institute of Advanced Studies (UNU-IAS) is also taking an active role in the sustainable urban development dialogue.

Although urban growth rates are slowing down in most regions of the developing world, levels of urbanisation are expected to rise, with the least urbanised regions of Asia and Africa transforming from largely rural societies to predominantly urban regions during the course of this century. By 2050, the urban population of the developing world will be 5.3 billion; Asia alone will host 63 percent of the world's urban population (3.3 billion people) and Africa, with an urban population of 1.2 billion, will be home to nearly a quarter of the world urban population. In sharp contrast, the phenomenon of shrinking urban populations can be observed in some cities in the developing world. Some issues to attend to include: greening the local economy; creating a green job work force; providing sustainable urban transport options; developing resource efficient buildings; implementing ICT solutions for smart and connected cities; and fostering waste minimization through a recycling-based society.

The focus of this paper is to trace and overview of artistic representations, fiction narrative and poetry in particular, which offer vision of human communities. Urban mindscapes oscillate generally between utopian ideas of garden cities and critical views of industrial environments. The study will review literature in the West and compare it to the case of contemporary India. The multiplicity of Indian modernity has allowed the emergence of very diverse mindscapes where indigenous values and symbols are preserved in the artistic practices of smaller communities. One example is the UttarAdhunik School of poetry in West Bengal. The graphic depictions and texts by one of its most relevant figures, Anjan Sen, redirects our thinking from the cityscape, territorially located, to the ever flowing migratory movements and other human settlements closer to nature. Artistic representations are an ideal medium for diasporic groups who frequently challenge the hegemonic memories established by dominant powers. It is through a kind of nostalgic lens that these collective 
memories are remembered and that postcolonial writers are able to redefine spatial history. Between the lines of this paper the varied meanings of 'modernity' for various segments of society emerge not just as cultural ideologies but also as political actions seeking to redefine the economic landscapes of our global world.

\section{Asia: a look toward the East of Eden}

Cities are large cultural and spatial systems, characterised by particular social, economic, and political practices and the power relations emerging from them. Four roles stand out: a) The city as an engine of economic growth, trade and transformation, b) The city as a social change agent and the crucible of innovation and adaptation; cities as centres of successful, dynamic progressive governance; c) The city, facilitating the exchange of ideas, goods and services, community experience and practices; d) The city as leader in healing environmental damage, championing public health, fair food production/distribution, enabling social equity to increase and as focus of global communication.

By the year 1900, only about 15 percent of the population or just 250 million people, lived and worked in urban areas, around 30 percent of India's population today. Over the next 100 years, the 250 million urban dwellers became 2.8 billion $(49 \%$ of India's population

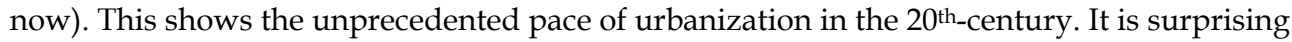
that the world has been able to cope with this rapid increase, and it is no surprise that the city appears prominently in all kinds of artistic and cultural representations. Geographically, the focus of change is now Asia and Africa. Europe and North-America experienced rapid urbanization in the $19^{\text {th }}$-century and early $20^{\text {th }}$-century. Latin-America followed in the second half of the $20^{\text {th }}$-century. By 2030 about $55 \%$ of the total world urban population will be in Asia. Recently, China has demonstrated an unprecedented constructive transition from an agrarian economy to an industrial society, from rural communities to urban settlements, from isolated towns and villages to a system of metropolitan communities. Demography is fundamental because, as history has many times demonstrated, the most populous countries are potentially the most powerful in terms of active workers. This power is correlated to the territorial distribution of the population as in the cases of China and India. History is important in both countries which are also places of very ancient civilizations.

The history of Chinese urbanisation is essentially endogenous (moving from the Yellow River to the Yangtze basin). In India the movement also started in the Indus and Ganges plains but the expansion was mostly determined by invaders coming from central Asia in the 13th century to establish the Delhi sultanate, then by the Moghol empire as of 1526, and the British colonisation from the end of the 18th century to the creation of New Delhi. In both cases the urban wave has moved from north to south. India's demographic growth is much faster than China's, due to a lack of family planning. The present growth rate of the population in India is estimated at 1.4 percent per annum, compared to a low 0.58 percent in China. The rates of urban growth are 2.7 percent per year in China (going down towards 2 percent) and 2.4 percent in India (going up towards 2.6 percent). In 2030, according to UN projections, China should be 62 percent urban and India 41 percent. The two countries have the same number of cities of more than five million people (eight). In China the largest cities are distributed along the coast: Shanghai, Beijing, Guangzhou, Shenzhen, Tianjin, Hong Kong, Wuhan and Chongqing. In India the hexagon Mymbai, Delhi Kolkata, Chennai, Bangalore, Ahmedabad and Pune covers almost the entire country. China and India demonstrate that 
cities are simultaneously the cause and consequence of development, that there is a direct correlation between urbanisation and socio-economic progress. (Paul Bairoch 1993)

After history, economy is the second explanatory factor of the urbanisation processes. If the two countries had the same per capita income in 1987, the figure has quadrupled in 20 years in China and doubled in India. At present the purchasing power per capita in China is therefore approximately twice that of India. The Chinese take-off has been much faster than India's, particularly thanks to the dynamism of its cities linked to an enormous investment in infrastructure and reforms. Chinese exports represented 10 times Indian exports during the last few years, but the relative gap will diminish in the coming years because of India's more liberal laisser-faire federal Government and political decentralisation after the passing of the 74th amendment to the Constitution in 1992. However, it is clear that India needs to drastically increase its investments in infrastructure. Monetary or income poverty diminishes regularly in the two countries, but the poverty of living conditions, which has decreased in China, persists in most Indian cities. This "housing poverty" is visible in the larger urbanized areas in India. Social inequities are also striking in India, specifically between unregistered migrant workers and the official urban population. The launch in 2005 of the National Urban Renewal Mission aimed at reducing poverty in Indian cities and was supported by federal budget and the active role played by NGOs in poor neighbourhoods. Regional levels of government and the transfer of financial competences have been essential in view of the immense size of the territory, and India is implementing international recommendations on the incremental upgrading of slum conditions with the participation of communities themselves, although there is an evolution towards high-cost speculative housing and the production of social housing by public agencies has not increased.

Asian cities appear to have in common the abolition of the centre-suburb dichotomy, which constitutes a feature of both European cities (which have a rich centre) and American cities (where the wealthy live in suburbs). In India, urban populations are relocating to suburban areas and satellite towns linked to the main city through commuter networks. This phenomenon is particularly prevalent in large Indian cities where ring towns or "bedroom communities" have formed around cities like New Delhi and Mumbai. Urban growth patterns in China, on the other hand, have tended to produce "city regions" along the eastern coastal belt, which are responsible for much of the economic growth experienced by the country in recent years. With some exceptions (e.g. Bangalore), Indian cities are becoming more and more multi-centred, due to investor strategies to promote metropolitan regions or urban corridors associating cities, towns and rural areas and favouring intraregional synergies. Acute regional disparities, insufficient energetic resources and huge environmental problems (air and water pollution, obsolete heavy industries) constitute major constraints and threats. In 2002 the Central Pollution Control board coordinated a project to make eco-friendly the towns of Vrindavan, Tirupati, Puri, Ujjian, Kottayam and Thanjavour. These initiatives fit well within a population that contemplates adherence to Western modes of consumption - private car, fast food, malls, modernist architecture- with an unhidden national pride and a longing for more traditional lifestyles.

\section{Western mindscapes}

In recent years, it is significant the number of urban studies that have focused on the cultural ideas of a community since practical outcomes of this analysis further the 
understanding of urban dynamics such as 1) how the relationship between urban scenery may affect people's sense of belonging; 2) how after urban change civic memory may still retain remembrances representative of the community; 3) how the dynamics of change whether environmental, technological, or cultural should ensure social justice and sustainable communities; and 4) how urban issues may affect conflict resolution between individual and communal demands such as mobility, equity, etc. Urban sociologists such as Bridge and Watson; LeGates and Staut; Palen; Keunen and Eeckhout have turned their attention to the artistic representations in order to understand social problems and develop normative theories and ameliorative plans to counter them.

The space of the city is conceptualized as a dwelling place drawn against its inhabitants and site of relational constructions where the limit or border becomes a constitutive feature, perceived as embodied, physical and territorial, a feature of individual, but also of collective identity: me and the others. The production of spatial finitude and delimitation of both space and time places the individual in the centre of perception. Existing things are felt (seen, heard, etc.) as fixed around us, placed against a particular point of reference. This is how the constructed space acquires a sense of territorial belonging. It is through this sense of belonging that the role of history, memory and art comes into play.

Prototypical representations, frequent in advertising and marketing, often construct the city from a range of places, architectural, spatial, social, or cultural images, elected as best to simplify and evoke a prototype easy to remember (i.e. New York the city that never sleeps). Artistic representations, on the other hand, are rooted in people's emotional experiences and seek to map the multiplicity of city life and the diversity of places and spaces, both individual and communal. In the West, work by Seixo; Weiss-Sussex and Bianchini have contributed to the study of city images transported through memory, imagination and cultural representation in different media. Rob Shields, Lewis Mumford, Françoise Choay, Henri Lefebvre, Paolo Sica and Richard Sennett discussed the use of artistic and literary sources to document urbanization processes.

The $18^{\text {th }}$-century novel was the point of departure for Morroe Berger's, Oscar Handlin's or Pierre Ansay's studies on urban growth and industrialization (the same can be found in and René Schoonbrodt's volumes). Andrew Lees's volume includes both literature and journalism in the configuration of European and North American city spaces. Other studies include work by Michael Jaye and Ann C. Watts, Arturo Almandoz, or by Richard Lehan, who argues that transformations in the structure and function of cities influenced the form of the novel so that the various narrative methods and trends can be linked to historical stages of urbanization. J. Hillis Miller has proposed that every narrative without exception, even the most abstract one, "traces out in its course an arrangement of places, dwellings, and rooms joined by paths and roads" (10) Thus, streets, squares, arcades, buildings, etc. -- can be interpreted as visible signs of social, economic and political processes, conceptualizing the city as a composite of representational human acts (see also Spiridon; Verheyen; Relph). Recent research shows how that these representations of urban spaces are changing from the evocation of the physical structures of the city -monuments, public buildings, cultural attractions, to signs and meanings shared across the online communities of cyberspace. A clear symptom of the questioning of the communicative space of the city is the emphasis on meta-cognitive articulations of the awareness of limits and their symbolic representations. A certain desire to transgress limits or to articulate 'in-between' and 'third spaces' emerges as 
symptom of structural problems at the spatial-temporal interface of culture and its representations, and it points to the principle of semiotic practice which allows intersubjective formations of signification and meaningful action, negotiated in political, social, economic and technological practice (see López-Varela and Net 2009)

The utopia of an ideal Ur-image as a perfectly organized communal space is an enduring theme in the oral and written tradition of all cultures, standing at the crossroads between imagination and experience and forming part of the creation myths in many cultures. For example, sources for the biblical Garden of Eden can be found in earlier Canaanite and Mesopotamian myths accounted for in the Enûma Eliš, and in the Iranian and Zoroastrian traditions. In the Western tradition ancient works such as Plato's Republic, Saint Augustine's City of God, Virgil's Aeneid, Moore's Utopia, Dante's Purgatory, Bacon's New Atlantis, or Campanella's City of the Sun, include "loci amoeni" of perfect societies, myth that widely circulated between Asia and Europe thanks to travels and conquests of Alexander the Great (356- 323 BC). The idealization of rural communities in the West, has been particularly prevalent at times of fast industrial growth, and accompanying fear of the loss of the individual in mass humanity as well as ecological threats and environmental issues. The theme has frequently appeared in association to issues of femininity as a kind of essence, home, place of shelter and mother earth figure, exemplified in the Greek myth of Gaia. Works by English poets, such as Worldsworth or Keats emphasized the need to recover the appreciation for the bond between natural resources and human habitation. In contrast to this idyllic garden community, cities have frequently been associated with vice, with the earliest references in the West being the biblical mention of Cain as the first city-builder and the fall of Babylon. Dystopic representations of cities prevailed during the Enlightenment in the work of satirists such as Jonathan Swift's Gulliver's Travels, but more importantly in the romantic and Victorian imagination. Gothic literature disclosed a criticism of science and technology associated with enclosed and dark places (castles, corrupt cities). Corruption in cities is a theme frequently found in Charles Dickens, Cowper or Thackeray, and even more

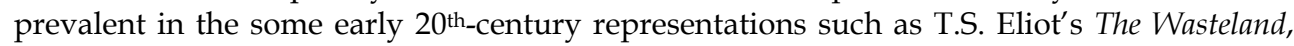
Wells's The Invisible Man and The War of the Worlds, or Huxley's Brave New World. In Chaplin's movies, such as Modern Times or, more recently, in Margaret Atwood's novels, the city is again the place where technological advance, works alongside totalitarian regimes and dehumanized capitalist trends to suffocate the alienated individual in the mechanized metropolis. Selfish individual desires and the power of money lead to desolate urban wastelands, and the increasing diversity of the crowd seems to engulf differences into the mass, as Eduard Munch exemplified in 1893 in his famous painting The Scream. Modernist representations and their emphasis on the spatial and temporal relativity (the subjective versions of time that we can find in authors and artists as different as Bergson, Proust, Woolf, Joyce, Magritte, or Dali) indicate a desire to encapsulate time into space (Woolf's "moments of being", Joyce's notion of "epiphany"; for more information see López-Varela 2004). In many of these works, the metaphor of the journey or voyage, a symbol for movement, openness, freedom and progress becomes an endless cyclic and insecure urban wandering, almost trapping the individual. Y.F. Tuan writes that this open space, with "no trodden paths and signposts ... has no fixed pattern of established human meanings ... Enclosed and humanized space is place" (54). Why should space become place in modern representations? In the West, interwar existential place becames Dasein, a situation in discourse, a place of paralysis where the individual seeks an impossible fixed identity, 
possibly associated to the fact that many of these artists were in exile during and in between world wars.

Acknowledging the significance of national context in literary texts, Richard Lehan describes how responses to the modern city varied across space. While feudalism, imperialism, and totalitarianism informed European urban literature, American authors, artists, and architects reacted to and in turn shaped images of the frontier, the transition from rural to urban and with the perceived democracy of the frontier (167). Lehan introduces the category of region into his analysis, noting differences between depictions of the city in the North-Eastern, Southern, Mid-Western, and Western U.S. In late nineteenth- and twentieth-century representations cities are given the role of signs in the economy of consumption. Protagonists in US-American novels are the ethnically marked inhabitants of growing cities, belonging to a class-spectrum ranging from the destitute to the lower middle-class. This is the case in many naturalist literary portraits of cities, such as those by Dreiser's Sister Carrie and texts works by writers such as Ellen Glasgow, Jack London, Steven Crane, or Frank Norris, many of them committed to socialist ideals in the United States, influenced also by European writers such as Zola. The hard-boiled detective novel, which originated in Los Angeles in the 1930s, displays the image of the perverse city in the detective stories of Raymond Chandler and James Ellroy (further examples include such as the technocratic depiction of Los Angeles in which computers, cyborgs, and technology have gained control over society in Neal Stephenson's cyberpunk novel Snow Crash and in films such as Strange Days or Blade Runner).

Modern representations of urban communities as cities of things and cities of signs derive from industrial capitalism and post-industrial capitalism. The dominance of commodity fetishism is apparent in works by Warhol and in pop art in general, where objects and things are given a defining role in determining meaning. The next step is the city of signs, where post-industrial media culture replaces "things" for "signs". As Deleuze and Guattari explain "from the moment we place desire on the side of acquisition, we make desire an idealistic (dialectical, nihilistic) conception, which causes us to look upon it as primarily a lack ... a lack of the real object" (25) Thus, consumer capitalism mobilizes desire to produce active subjectivities rather than the passive ones portrayed in Baudelaire's flâneur. The spectacle of the city is a cause of discontent because it offers more experience than humans can assimilate, Restless dissatisfaction and aimless desire ensues.

Malcolm Bradbury writes that the fascination with the city has much to do with its growing size and heterogeneity: "not simply a national capital, but a cosmopolitan city ... the capital of an empire and the centre of world trade." (179). Modernist Western perceptions of the city are modular in that they displace undesirable social elements to the periphery or the regions that Michel Foucault termed heterotopoi: the madhouse, the prison, the "red light" districts, the bowery (24). The modularity of city life appears also in early motion pictures, such as Chaplin's Modern Times or Naked City and in the criss-cross of train tracks, subway lines and continuous movement of the masses in Lang's movie Metropolis or John Dos Passos' novel Manhattan Transfer. "A fragmented and subjective kaleidoscope, constantly shifting in time" (Pike xiii) the modernist city opens up spaces, inviting audiences to familiar places that are simultaneously archetypical and strange, like "a second poetic geography" that comes "on top of the geography of the literal" (de Certeau, "Walking in the City" 159), "punched and torn open by ellipses, drifts and leaks of meaning" (160). 
As the modern approaches the post-modern the construction of spatiality takes a different approach breaking the order/topos-chaos/chora dichotomy. The concept of site (as in website) becomes nomadic and there is a return to bounded-chaos approaches since excessive order is perceived as oppressive. With the introduction of digital media and the widespread use of social networks, relational space is reduced in terms of physical distance but also in terms of physical contact. The post-industrial city offers alienated visions of humanity amid the overload of informational signs, exemplified powerfully in Thomas Pynchon's novels and in Paul Auster's short narrative City of Glass (see López-Varela 2012)

\section{Eastern mindscapes: India}

Regarded by many historians as the oldest living civilization of earth, the Indian tradition dates back to $8000 \mathrm{BC}$, and has a continuous recorded history since the time of the Vedas, believed variously to be 3,000 to over 5,500 years ago. India is racially, culturally, linguistically, ethnically and religiously the most diverse country in the world. Its culture has been shaped by its geography, different demographies, and a long history of diverse settlements, invasions and cultures. Social and cultural restrictions are still defined by thousands of endogamous hereditary groups, often termed castes. This variety has determined communal differences which in their long co-existence have enabled the proximity of many cultural and religious views, mainly Hinduism (practiced by $80 \%$ of the people) and Buddhism. The two main language families in India are Indo-Aryan (a branch of Indo-European) and Dravidian.

In South-Asia, traditions that inform religions such as Hinduism and its variants (Brahamism, Vaishnavism, Jainism, Shaivaism, Shaktism), Buddhism, Sikhism, and in the East-Asian Taoism and Shinto, retain a cyclic view of time where the sacred lies outside the flux of the material world. Like Platonic and NeoPlatonic explanations, death is associated with freedom and escape from the bondage of the temporal human condition. Unlike Western ideas of Paradise, in these traditions Nirvāna is a state of transcendence involving a subjective experience of deep release and happiness, the result of a natural re-ordering of the mind and body via yogic discipline. In Jainism, the Kalpa Sūtra text, describes the crescent shaped Siddhashila, a place where all siddhas (liberated souls who have discarded their mortal body) reside after Nirvāna. In Hindu theology, Siddhashrama is a secret land deep in the Himalayas, where great siddhas live. Siddhashrama is referred in many Indian epics, including the Rāmāyaṇa and the Mahābhārata (aprox. 400 BC) the oldest preserved and well-known epics of India.

In the Vedas, the earliest Indian texts dating back to the late 2nd millennium BC and describing ancient Hindu cosmology, the universe goes through repeated cycles of creation, destruction and rebirth, with each cycle lasting 4,320,000 years. The Markandeya Purana one of the major eighteen Mahapuranas, a genre of Hindu religious texts, describes Hindu Paradise as seven concentric heavenly worlds and seven oceans. Jambudvipa forms the innermost concentric island, narrow in the south and north and elevated and broad in the middle. Its name is said to derive from a Jambu tree (blackberry) and at the center of the elevated region lies the golden Mount Meru with the vast city of Lord Brahma, Brahmapuri on its summit. Its river, Akash Ganga, issues forth from the foot of Lord Vishnu and, after encircling the city, splits into four mighty streams that flow in opposite directions, North, South, East, West irrigating all the lands of Jambudvipa. The righteous (devas) live in this paradise while awaiting their next reincarnation. 
This description shows that in South-Asian traditions, Paradise is not contemplated as a fixed location at the end of a historical journey towards sanctification, but rather as a series of existential planes, traditionally envisioned as a vertical continuum in the shape of a mountain, with heavens existing above the realm of world living creatures. This visualization is directly related to the differences religious conceptions of resurrection and reincarnation, and impacts directly in the visualization of Paradise as ideal community.

Garden-cities may have originated as early as 4000 BC, when the idea of Paradise spread through Persian literature and Hellenic influence into Europe and North Africa. The Persian word for walled-garden eparidaida rendered the European "Paradise". Hebrew pardes referred to a park, garden or orchard (see the Song of Solomon 4:13, Ecclesiastes 2:5 and Nehemiah 2:8) In the New Testament the word is used in Luke 23:43, 2 Cor.12:4 and Rev.2:7 in a reference to the Gen.2:8 and the tree of life. Besides, the story locates the garden with reference to four rivers (Pishon, Gihon, Tigris, Euphrates) and, as in the Indian tradition, they charted the four different directions North, South, East and West. The garden-myth contemplates location in relation to the birth of sexuality (locus amoenus), and therefore community. The enclosed quality of the garden was meant to protect physical and spiritual relaxation, and eventually came to refer to a plantation or cultivated area, not necessarily walled. Gardens were decorated with fountains and ponds and four streams dividing the four areas of the world. The design changed into a central pool with a long axis and a cross axis extending water channels into four gardens, a pattern visible in the garden of the Alhambra in Granada, Spain and in the Taj Mahal. The first Persian garden in India seems to be the work of Zahīr ad-Dīn Muhammad (1483 -1530), a descendant of Genghis Khan, who was the first Mughal Emperor to invade South Asia. He established Aram Bāgh garden in Agra. In the Islamic tradition, the descriptions of paradise are mentioned in significant detail in the Qur'an (610-632 CE)

The different views of Paradise between ancient South Asian and Mesopotamian traditions are related to the distinct conceptions of temporal flow. In both traditions the universe is infinite, but the three Abrahamic religions, Judaism, Christianity and Islam, postulate a difference between sacred and profane time, with human creation (Genesis) as starting point. South Asian religions, however, belief that time is infinite, like the human soul, and it follows cycles. Contemporary scientific explanations see time as a dimension of space, in that future events are already there. The simultaneous experience of time cannot be captured from a human perspective. Thus, humans contemplate time as a succession of moments (past, present, future) in relation to perception and memory. The contents of an observation are time-extended but the conceptual observer, being a geometric point at the origin of the light cone, is not (see López-Varela 2004). In religious mythical imagery, a cosmic center or axis mundi would help connect the two planes, the sacred (Heaven) and the human world. A frequent element in all cosmologies is the tree or a pillar (ziggurat, temple, etc.) joining the two words.

These foundational stories are closely related to the development of communities, cities and nations. Generally, human control implies the removal of the uncontrolled, dangerous and wild, and sometimes the taming of nature. However, the envisioned garden-community also seeks to preserve ecological relations and not degrade human life and nature with polluting and unhealthy habits for the community (among them heavy industrialization, prostitution, etc., frequently associated with urban spaces). The mythical images captured in artistic 
representations bring forth important human concerns regarding social life in what Benedict Anderson termed 'imagined communities'.

The balance between the imagined and the real was the object of Edward Said's critique of orientalism. The perception of space (a territory) and time (its history) is constantly created and re-created in cultural representations (images, texts, discourses). Frequently, these prototypical representations are instruments of institutional power and provide a means to control and subordinate some areas. Power often lies, and even more today in the age of media communication, in the hands of those who have the means to objectify those who they imagine. Said's notion of "imagined geographies" shows the inequalities created in the construction of representations about other (different) regions and societies.

Western imagination has tended to contemplate India as a nation of small rural communities identified with nature, and whose artistic geography has been put in relation to the abundant mythology, ancient history and spirituality that strongly infuse all levels of India's life and art. But today, Indian diversity comes across in the iconography of its everyday communal life, rendered in the cities in the form billboards and posters in the streets, automobiles and shops, exhibited in art galleries and discovered in bazaars, TV adds and film posters. In the last two decades, India has become one of the fastest urbanizing countries in the world. Yet, it has not given up its historical past and social structures. This rapid process of urbanization often leads to variable levels of spatial, social and economic marginalization in the case of the poorer sections of urban populations. This is mostly due to uneven coverage by public and private enterprise, uneven distribution of investment, and frequently the absence of social safety networks. In the history of the West, the liberalization of the economy associated to industrialism generated an increase in social differences that eventually led to discontent and revolutions. These problems have not been solved yet. In a working paper for the US National Bureau of Economic Research entitled "The divergence of human capital levels across cities", Christopher R. Berry and Edward L. Glaeser (2005) present a model showing the relationship between the clustering of skilled people in metropolitan US areas, and urban size, measured as population. These findings account for roughly 25 to 35 percent of the total increase in economic inequality across cities over the past three decades in the US. The solution lies in developing strategies to turn low-wage unskilled jobs into higher-waged skilled positions and build a more robust social safety net to address the persistent problems of the disadvantaged. State measures to facilitate education and training to the poor are fundamental. The last part of this paper turns to artistic representations that illustrate some of the concerns, fractures and tensions created by rapid changes in technology, industrialization and urbanization, and that frequently confront the imaginaries of local communities.

\section{West Bengal and the UttarAdhunik school of poetry}

The rapid growth of population in India, with 26 cities expected to host over 1 million inhabitants by 2030 is sometimes contemplated as a source of hope for the suffocating Western economies that expect to see an increase of commerce with the two Asian emerging superpowers, India and China. In the last ten years urban population in India has reached 30 percent of its total population. Many changes to the cities are coming from long-time residents, who are becoming more prosperous and invest in new industrial goals. After 
independence, several new cities were built and older cities such as Varanasi or Hyderabad, grew into state capitals. Other urban centres under colonial rule, like Kolkata, favoured bourgeois cosmopolitan environments that linked European commerce to South Asian regions. Mumbai, Delhi and Bangalore are becoming the world's largest megalopolises and cultural centres of growing significance, with Bollywood, Bhangra Beat and Asian Dub increasingly playing a formative role in global pop culture. All these spaces reflect the complex interrelationships between globalization, local traditions and redesigned living spaces.

As in other developing countries, India's modern popular imagery has resulted from the major cultural and technological shifts during 19th and 20th-centuries. Mass production of images, new means of visualising myths and religious legends have produced a huge eclecticism of images. The copy-paste world of Internet virtual images facilitates an ambivalent collage of representations that equates with the global appropriation of aesthetic and cultural content at a transnational level. Today's image economies are, more than ever, economies of mobile World Wide Web signs (López-Varela 2012). But although the city may be an ideal place to translate cultural forms into artistic practices, the contemporary art production is no longer just located in the urban centres. Utopian imaginaries coexist with dystopic representations where the disentanglement of communal bonds and the fear of losing one's sense of belonging take the form of fractured and polluted urban environments. With the proliferation of online technologies and social networks, this theme is being avidly discussed all over the world, as digital media is creating a general dislocation, not just of information, but also of issues concerning individual and collaborative production, creative commons and copyright, and opening up the spectrum of communal life in general.

In West Bengal, a group of popular poets have been discussing about what they describe as an "overpersonal (Uttar-Vyakti) moment" of total personal individual growth, but simultaneously deeply social. The group, which Amitabha Gupta called UttarAdhunik School of Poetry (Janapad 1985), has vowed to put the socio-cultural context at the very centre of their poetry and react against the individualism of modernity and post-modernity, and the market-guided reality prevalent in India since the 1960s and 1970s. UttarAdhunikata looks back at Indian mythology and folklore, ballads and music, drawings and paintings to bring in a plurality which combines individual's idiolect and sociolect, and contemplates authorship as a group and inter-genre activity. As in the Siddhaachaaryas and Vhaisnava Mahajans, in work by Shakta poets, in Kalighat or Birbhaum drawings and many terracotta panels in temples, the hybrid integration of artistic units in a series of compositions is frequent, and these works were frequently the result of the participation of several generations of artists.

A continuation of the breach between Western and Eastern space-time conceptions, Indian art shows the fluid diasporic nature of location, authorship, representation and genre. One example can be found in the differences between Greek and Indian myths regarding the origin of music. In both cases, female deities personify sound patterns, but while the Indian classification refers to time-sequences (Raaga Puurabii, for example, is about the evening, and Raaga Bhiaron about dawn), bridging the sacred and the profane and integrating female and male incarnations (Raagini and Raagas), the Greek cannon uses female goddesses (all daughters of Zeus) who differ in the themes they present (Clio, for example, is the music of 
historical songs; Terpsichore, of songs on dawn, etc.). The concept of Vaak (the voice the word it utters) is relevant here and refers to the activity of speech as a cohesive force which unites sounds and words. Similarly, "UttarAdhunikata is a "textual integer", an expression coined by Amitava Gupta, to explain the textuality that interrelates poems connected into a narrative that fuses past and present, individual and communal and collective consciousness.

Sen explains that UttarAdhunik is not a movement but rather a stirring, a musical tone, an emotion, a puzzle or perhaps an anxiety. Quoting Niharranjan Ray (1968), Sen describes the notion of social subjectivity represented by the Indian concepts of 'Kula' and 'Sila'. A person is introduced to his/her social world in terms of his/her KulaSila. "Kula is heredity, inheritance, which is both biological and cultural, together constituting what we call tradition." (Ray 1968: 6) Kula takes place in a particular context and human situation and carries "particular problems, obligations and challenges" In these encounters the person develops ideas, visions, images, symbols, and modes and methods of thought and action, becoming aware of this inheritance $(\mathrm{Kula})$, and responding and articulating these modes in particular ways, thus determining his or her Sila. (Ray 1968: 7) Myth is not a passing reference in UttarAdhunik poetry. In order to bridge the gap between Kula and Sila, between the past and the present, the UttarAdhunik poets use traditional myths as part of present history. Teleological (linear) time and history are understood as objective (scientific/empirical) response to the conflicts presented in myth (Hegel's dialogical approach is based on a synthesis of opposites, something unthinkable for Indian conceptions of coexistence of multiplicity).

Any theory is inevitably bound within the periphery of country, time and word - even the basic physical characteristics of the theory-giver leave their imprint on the nature of the theory. Everybody lives in a specific country and time, and expresses his mind through words - the thoughts and attitudes of his countrymen are always there in his conscious and unconscious self. Tradition is created in this way. This tradition can also be called a cage. But in the cage itself lies the possibility of an achin pakhi (unknown bird) that transcends the cage. (Chakrabarty 62)

The well-known poem "Darao Pathik" (Stop you traveller), written by Anjan Sen, addresses some of the issues just discussed:

Stop you traveller

If you were born in Gourabanga

If you've heard padavali mangala

Panchali prasadi Madhu Rabindra

Stop for a moment

If you were born in the land of floods, drought and good harvest

You'll say language is all around you. . .

Language is simmering inside you

Bangla bhasha

Whenecer you want to say my Bhasha

You're losing voice hands and tongue

Stop, Traveller, stop for a moment

Say, hope is the mother tongue

(translated from Bengaly by Khandakar Ashraf Hossain) 


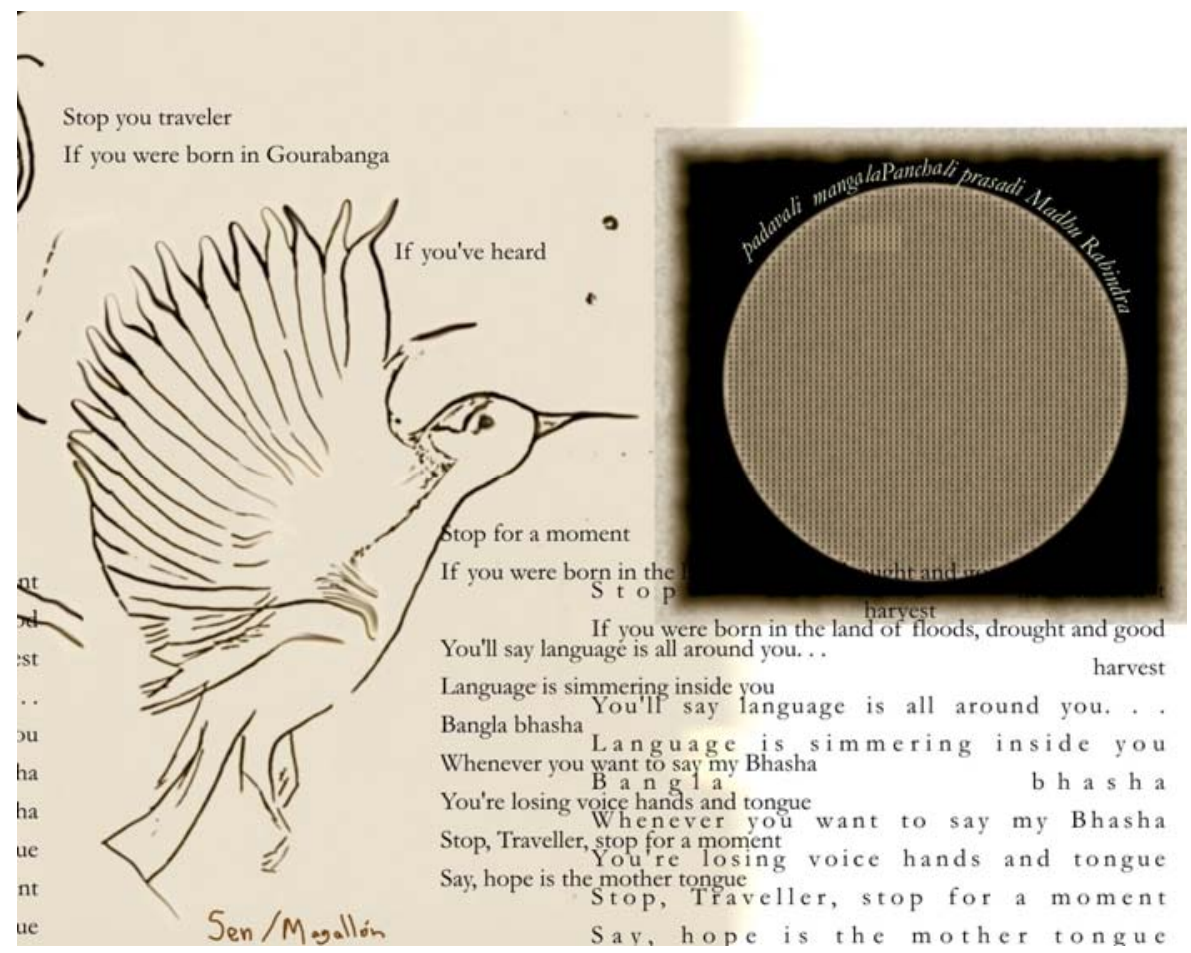

The poem's keywords, "born in Gourabanga...the land of floods, drought and good harvest", with "language all around you", "simmering inside you", refer to the inherited past, carried by the traveller in his/her movement. The poetic subject asks the traveller to "stop for a moment" and recover his/her "voice hands and tongue". The poem/song ends with the line "say, hope in the mother tongue", emphasizing that Indian myths and traditions (mother tongues) are a source of hope and freedom for UttarAdhunik poets. The illustration of the poem also refers to this fact by depicting a bird of heavy plumage flying into the sky.

Sen's poem also refers to the "travelling across" (time and space) of certain elements in Bangladeshi poetry. Sen's essay “Ashir Kabita, Grihey Pherey Bhramonik Chokh" which appeared in Ekobingsho (March 1992) graphically showed the similarities between the writings of poets on both sides of the border:

What a striking unity between Lalon Fakir and Ramprasad Sen. Although as poets they belong to two different religious and social classes. Actually what makes them attractive is their love of man which is not to be found in modern poetry. Similarly, there are affinities between the poetic languages of Shah Muhammad Sagir, Chandidas and the padavali poetry, though their subjects are different. Sufi-Sahajia literature also is a great treasure of Bangla literature: in it there has been a synthesis of various religions." (Sen in Chakrabarty 1991: 10)

Many of Anjan Sen's poems focus on spatial dynamics, rather than on cartographic representations. The journey and migratory movements are a constant theme, and the echo of nostalgia for lost traditional roots resounds in many of the verses. 
Flowers bloom in the footsteps of one who goes

Pulling away all attractions and burdens

And while going, sweat stains the chosen path.

Flowers bloom, the journey becomes meaningful.

A flurry in the path of speech

Oblique attractions

Started, one hesitates

And goes again

And in going words become fire and water

Earth and universe.

Speech continues

And the earthly rhythms of common speech

Become verses

Going.

("Journey" translated from Bengali by Amlan Dsgupta; Illustrated by Diana Magallón 1989)
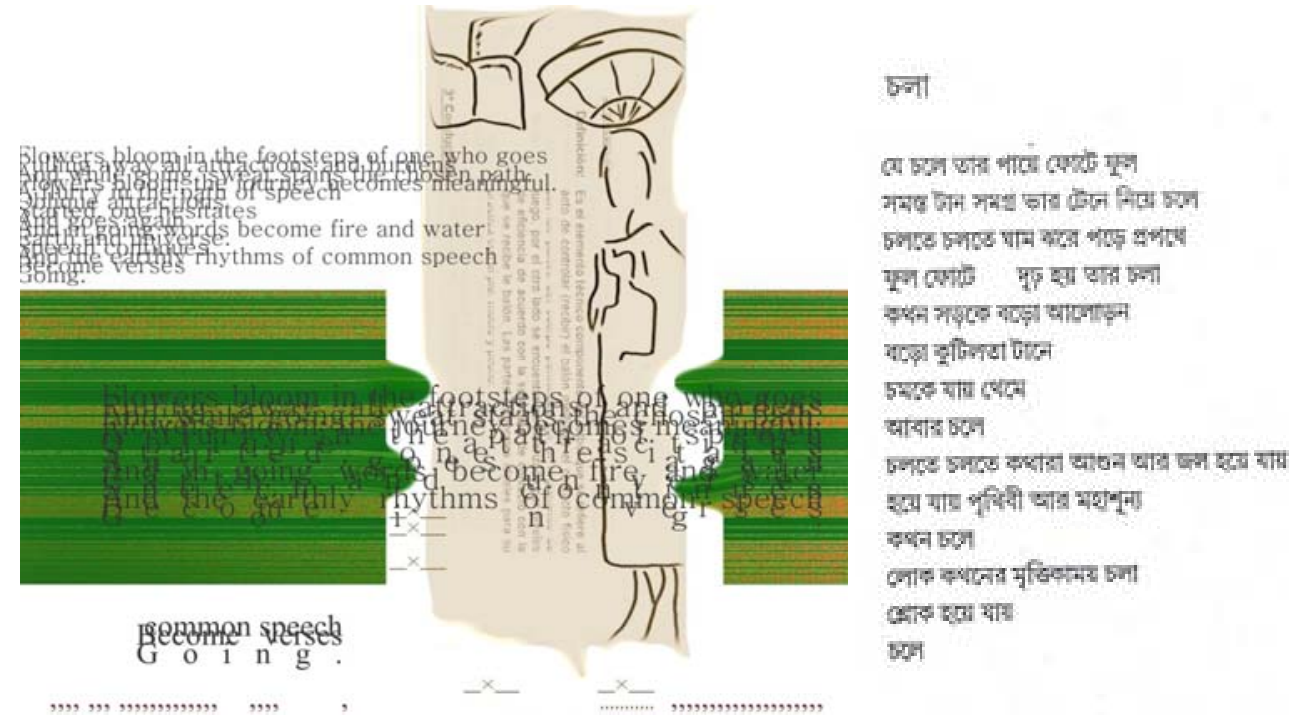

The philosophy of UttarAdhunikata does not see distinct cultures as mapped and detached realities, but rather as a system of inter-relations in continuum influx. Unlike the nostalgic modernist use of myth to capture the past in the present moment, West Bengal poetry understands temporal happenings as eternal recurrences, in line with traditional Indian conceptions of the universe. Time is a continuous wave of states of being which include past, present and future simultaneously. The individual moment is contemplated in relation to eternity or timelessness. And since the 'reality' of time is always set against the background of space, timeless time can only be thought within spaceless space, that is, infinity. Both eternity (the temporal dimension) and infinity (the spatial dimension) of humanity are, according to ancient Indian traditions, in perpetual flux or change. 
One of the striking characteristics of Anjan Sen's poetry is its simplicity. It comes across despite the intertextual references to classic Indian myths, history and folk traditions. Besides, Sen has actively encouraged the conversion of his words into visual art, crossing the border between text and image, and employing different formats, not just illustrations but also digital art forms (employed for instance by the Mexican artist Diana Magallón) and base-relief (as seen in his poem "Imagination" illustrated by sculptor Bimal Kundu, below). Furthermore, although Sen himself has illustrated many of his poems, he has also invited artists from diverse cultures to put images to his words. This is a direct way of involving his audiences into co-creation, making his own work more open, public, and intersubjective and less private and individual.

Anjan Sen is also happy to find the reflection of the tolerant coexistence of multiplicity of world views and religious symbols and tropes in his own poetry and in the poetry of the young Bangladeshi poets. In his critical works, Sen has explained that "In the literature of every language there are some elements which are the properties of its own. This is seen in that a particular image, subject or idea or context comes back again and again in that literature. Perhaps it changes its external form in the hands of different poets, but it does not become another text or influence. It manifests itself in intertextuality" (Sen: 1991, p. 36-37) References such as anno (food) and dhan (paddy) are reminiscent of folk life. They are found, for instance, in an old spell about dhenki (a wooden pedal used in husking rice). These metaphors bring back the awareness of the native soil.

So many seeds grew into plants

So much gold was reaped

The farmer's daughters walk round the heaps of paddy

Making the shrill 'uloo' sound

The festival continues all morning

The dream of more anno

After that dry soil again

No seed no water

("Krishir" [Of agriculture], translated from Bengaly by Khandakar Ashraf Hossain)

Similarly, "The Hunger" expresses the need for a return to the mythical and the traditional; the need to stay hungry, to dominate the capitalist desire to consume until everything is exhausted, including creativity. Again, the simple visuality of the poem is easily accessible to the reader:

Tell me - who will you eat, and eat how much

That 'll make you fat as a grampus

Fire in the large hearth does not quench

Melts glass molten iron

Crops get burnt out

Even that will you lap up

Devour sweetness and its joy?

Life becomes a listless corpse as it corrodes

You 'll eat corpse cadaver - you 'll eat all

And will grow into a pile in the capital market

Killing the deceased over and over again 
My hunger lies in his hidden tongue

Tell me how much more will you eat

How much more that' ll make you immense

("Hunger"; Translated from Bengali by Udaya Narayana Singh)

"Sharavan" is also about creativity; Here Anjan Sen uses metaphors of harvest and fertility. During the month of Sravan, a large section of Indian people perform a ritual in which they carry water on their shoulders and travel for around $50 \mathrm{Km}$ to pour this water on god Shiva, the Indian god of fertility and harvest. Sen suggests that grain hardens and becomes a stone (ShivaLinga is the symbol of fertility, a black stone in the shape of a phallus).

In The Myth of the Eternal Retour, Mircea Eliade explains how many of these ancient agricultural and fertility rituals may have travelled from their original contexts, translated and interpreted in new cultures. Rituals around the world have many resemblances, possibly not just due to the fact of mutual influence, but also owing to the basic structures needed to maintain human life in Neolithic times. Grain is a sources of food and energy and a symbol of new life and creativity (i.e. holy bread in Christian Communion) Water is a sources of cleanliness and new life (i.e. Baptism) and helps grain to grow properly on the land, just as food helps human physical and spiritual growth. Echoes of these rituals can also be found in the Egyptian Book of the Dead and in ancient Celtic fertility rituals (see The Golden Bough by Sir James Frazer, and Jessie L. Weston's From Ritual to Romance, both sources of T.S. Eliot The Wasteland). These myths are related to a cyclic conception of time in which the ritual is used again and again at the end of the cycle in order to clean, and prepare the land for a new start (also in a metaphoric sense where the land stands for the physical and spiritual human body). As Eliade explains, the cyclic ritualistic (illo tempore) conception of time (still welcomed in contemporary societies every "New Year") provides a sense of relief against the linear flux that ends in death. In most religions, after the "apocalyptic" moment of the end of physical time (life) there would be a possibility of return (reincarnation or resurrection).
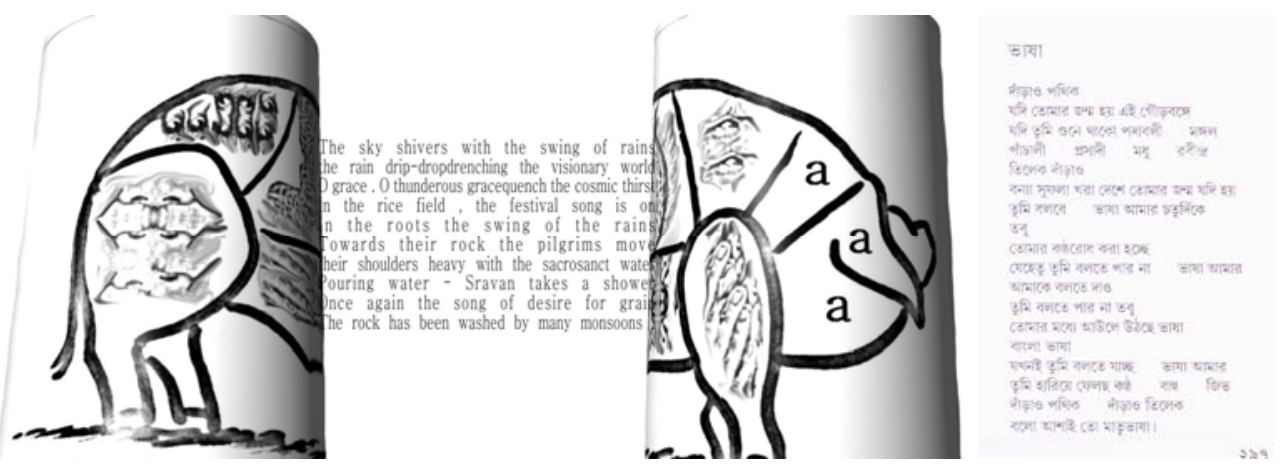

The sky shivers with the swing of rains

the rain drip-dropdrenching the visionary world

O grace . O thunderous grace, quench the cosmic thirst

In the rice field, the festival song is on

In the roots, the swing of the rains

Towards their rock the pilgrims move 
their shoulders heavy with the sacrosanct water

Pouring water - Sravan takes a shower

Once again the song of desire for grain

The rock has been washed by many monsoons.

("Sravan", translated from Bengali by Amlan Das Gupta; Illustrated by Diana Magallón, Mexico)

Krishnanjan Bhattacharya indicates that UttarAdhunikata recognizes cultural continuity and does not see distinct cultures 'detached realities', but rather as a system of inter-relations in continuum influx. (Bhattacharya 2004:184). The dynamic conception of UttarAdhunikata, unlike the nostalgic modernist use of myth to capture the past in the present moment, understands temporal happenings as eternal recurrences; a continuous wave of states of being which include past, present and future simultaneously (see Nikan 1967, Gupta 1991, Nundy 1992). Therefore, the question of seizing a moment of recollection as if suspended in time, present in Wordsworth's romantic poetry, in Joyce's notion of 'epiphanies' or in Virginia Woolf's 'moments of being' does not arise in UttarAdhunikata.

A post-post-modern conception (if labels were still in vogue) would be closer to what Anjan Sen has in mind: the inter-relatedness, dynamic and rhythmic, song-like flow of time and life, and of the substances of which life is made, both material (Sen's uses the mythical basic symbolism of earth, water, air/sky) and psychological (an emphasis on the affective and the aesthetic). The feelings that such a vision enables are captured in the metaphor of flowing and cleansing waters in Anjan Sen's poems below, and in the illustrations that accompany the poems:

And flows goes on

Standing rock- deep in the holy river, the hibiscus sky

Where hast thou come $\mathrm{O}$ river

The flowing locks of the destroyer, in mountains

When the fire of the skies cool, water

Drenches the soil and soothes the eyes

Life flows on through the rain,

And men discuss it as hope

And sing its praises

Call the river their mother,

Sing hymns

In their primal, magical belief

Sky rain mountain river water

Flowing

(“Flow” 1989; Translated from Bengali by Amlan Das Gupta)

UttarAdhunikta seeks to consider social accounts (both mythical and historical), alongside individual perceptions within the aesthetic. What this means is, in fact, an attempt to question the traditional division between myth, history and poetry, and formulate a kind of inter-generic hybrid position.

History, as formulated by Aristotle in his Poetics, has always been associated with chronological narratives of political events, frequently wars and the establishment of new 


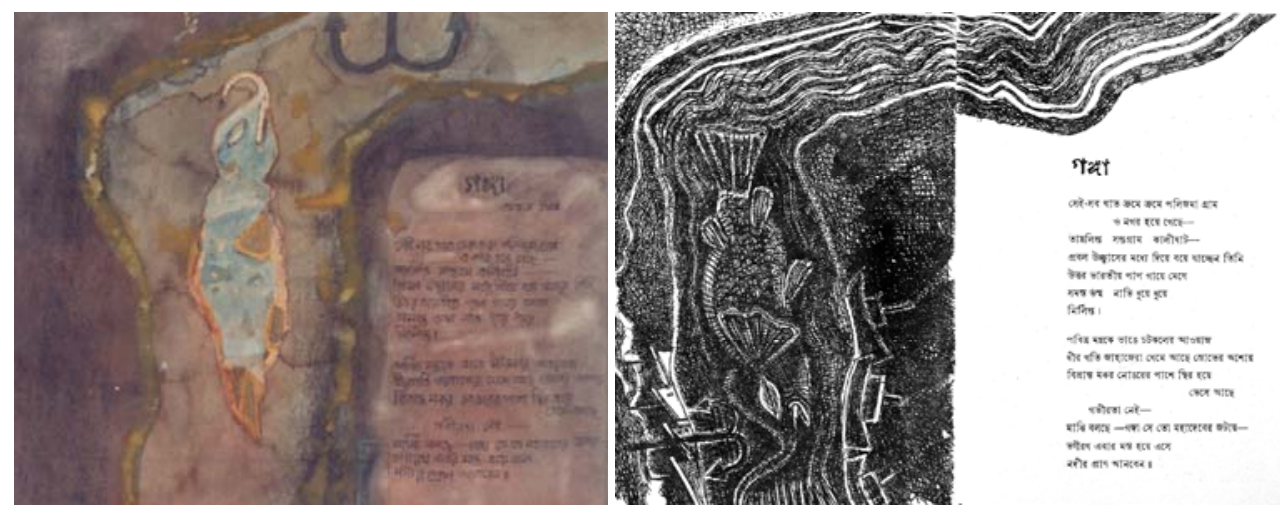

Fig. 1. Ganga -painting in mixed media by Ganesh Pyne // pen \& ink drawing by Ganesh Pyne

communities and nations. As such, it has been considered a 'serious' discipline, not to be associated with fictional narratives or myth. Research on narratology (i.e. Dorrit Cohn and Käte Hamburger) has signalled this separation as unfounded, based on the distinction between fact and event and on the separation of the narrative voice from its authorial origin in order to follow the empirical need of objectivity. The essential difference between historical writing, myth and fiction, is the claims of the first to be a truthful account, the record of fact. Fictional writing, on the other hand, is characterized by a built-in license to create an individual personal world, including the right to flaunt that license. The desire to break the borders of history (official collective memory), myth and poetic fiction (personal memories) is, therefore, related to the understanding of life as inter-subjective flux where the social and personal, objective and subjective, real and imaginary, factual and fictional, merge.

Another criterion for distinction between historiography and fictional texts is the overall configuration of the time sequence of events. Historical narratives are generally chronological and forward-looking, moving from cause to effect (teleology). In fictional narratives the characters' recollection and memory may preserve only some of the reported order. A retrospective de-chronologizing memory based narrative moves from effect to cause and the characters might eventually disclosed in opposition to the reader's previous assumptions. However, the fracture of time-sequences might also occur in non-fictional genres such as autobiography, which is predicated on a necessary forgetting or distancing to achieve objectivity.

While potentially a source for remembrance, the material traces of the past might be structured by omissions, restrictions, repressions, and exclusions that incite, even as they thwart, total recall. As such, they expose the ever present system of inter-relations inherent in processes of selection, assemblage and ordering whereby events are made into facts, and also into symbols. The fact is that which is affirmed (statement) of the event, and events need to be described so as to appear as facts. Thus, we can say that an event is a fact subject to description that is, telling. Fictionalization is involved in this process, since it can be considered the provision of a description that transforms an event in a possible object of analysis, that is, a fact. 
Hayden White's classic Metahistory works on the idea of "emplotment", a literary re-writing of events interwoven in figurative speech where the play between selection, organization of events, tropes and figures of speech problematize the borders between fact and fiction. White observes the tendency towards event dissolution as basic temporal occurrence in modernist narrative. (67)

Historian and literary critic, Dominick LaCapra has also questioned the borderland between historical discourse and fiction in an attempt to unveil the so-called "historicist phallacy" that alludes to the impossibility of explaining historical texts simply as contextual. In History and Criticism (1985), LaCapra considers two levels, intra-textual and extra-textual and questions if the opposition between fact and fiction is a polarity that excludes or, if on the contrary, both exist in a continuum of complex mutual interrelations.

Michel De Certeau (1988) proposed to examine the role of fiction and the unconscious in the production of a historical text. According to him, the notion of "anecdote" is fundamental because it allows for the creation of a gap in the narrative continuity of a larger story (grand narrative vs. petite histoire) and allows the irruption of chance events and discursive contingencies, bringing forth a break in temporal flux, a point of retrospection. For De Certeau, history can only be understood as a "lieux de mémoires", a social space that translates de exercise of memorializing in monuments to remember the past, a position close to that of Jacques Derrida in Archive Fever, where he points out the "presentness of the past", using it to project into the future.

The above suggestions problematize the differences between "fact" and "event", and between the re-workings of individual memory and the sociological symbolization process implied in the valuation of events in order a story into history. In 1946, Robin George Collingwood had also attempted to establish a separation between an inside and an outside of history. For him, the outside of a historical event consisted on the placement and movement of bodies in a given historical moment that happened in the past. The inside component was made of the thoughts of historical agents who relate historical events imaginatively, motivated by conscious thought processes that can be re-thought. However, Collingwood left out unconscious motivations, such as emotions and passions, signalling a cognitive human mind all made up of pure rationality (for the importance of the unconscious in autobiography, see Eakin 1985: 9; see aslo H. Porter Abbott and James Clifford 1987 for the importance of individual recollection in social memory and culture) Meir Sternberg has noted that inference-making relies on objective knowledge as much as in anticipation, prediction and other affective and interpersonal qualities, and explains that Aristotle's theory of catharsis builds emotions into a poetics of impact, chiefly regulated by affects (mimesis arises from pity and fear). Sternberg adds that the distinction between fiction and non-fiction is the result of this particular attention to impact (comic, tragic, comic, persuasive, illusionist, sublime, etc.)

To summarize the above discussion, one can argue that historical reality is comprised of a multitude of varied life experiences (events) which need to be negotiated into common experience (facts), both at the psychological personal and sociological levels. Events take the symbolic form of values that can be applicable to other times and other context, carrying more than one level of meaning. Values and morals are not simply thoughts and ways of 
reasoning; they are experiences. The root of values lies in the way experiences have a profound emotional impact on us, as if they were aesthetic experiences. Thus, it makes sense to explore the symbolic forms that represent values because the repetition of symbolic forms affects psychic and non-explicit levels giving way to their interiorization, both in personal and sociological terms. It is also possible to defend that fictionalization and myth are essential to the creation of the transitional realm that renders the representation of affective life experience in terms of generic hybridism, as the UttarAdhunikta proposes.

In his poem "Imagination", Anjan Sen uses the Indian concept of Kalpa, which refers to the endless fulfilment of desire related to the mythical cycle of creation and destruction. The poem points intertextually to Meghaduta-Kalidasa's Sanskrit epic in its desire to establish an inter-relationship between myths, history and poetry. Kalpadruma or kalpa-tree roots the future firmly into the past, but the dynamism of the circular time is achieved in the poem through various metaphors that emphasize floating up and down ("a grey cloud floated down") and falling ("dust kept falling"; "diamond coals ...falling"), the oscillation of bright ("diamonds") and dark ("coal", evening, etc.), and transformation (cutting wood, "the eyelid flickered"; "one bird...become Bihag"). Bihag is an Indian evening melody.

From the Kalpa began imagination

From the leaves of the Meghduta, a grey cloud

Floated down in front of us.

The Kalpadruma shuddered

Gold Silver dust kept falling

Diamonds coals mud kept falling

The eyelid flickered

One bird is flying become Bihag

A woodcutter was gathering wood from Kalpadruma

("Imagination"; Translated from Bengali by Amlan Das Gupta)

Research on the psychological aspects that encourage creativity started with Sigmund Freud's Mourning $\mathcal{E}$ Melancholia (1917), developed in the context of his personal experience in mourning the death of his father in 1896. Two years before, Freud had also written about the traumatic experiences of the World War in Thoughts for the Times on War \& Death. His study On Narcissism was published in 1914, where he develops further the relationship between mourning and melancholia as long-term outcomes of trauma, "even if the patient is aware of the loss that has given rise to his melancholia." (1917: 254) Dominick LaCapra introduced a distinction in the notions of absence and loss. The first involves the perception of something that was never present to begin with. Loss refers to a particular thing/person/event, but "when loss is converted into (or encrypted in an indiscriminately generalized rhetoric of absence, one faces the impasse of endless melancholy, impossible mourning" (LaCapra "Trauma, Absence, Loss" 1999: 698). Characteristic features of trauma are the secrecy and the silence surrounding it, symptomatic of an event whose core meaning has been permanently displaced--not known directly. Trauma can only enunciate itself as an enigma until such event can be brought back into consciousness through the act of speech, in which a listener or audience needs to be necessarily involved (psychoanalytic therapy or creative writing/art). Geoffrey Hartman also describes this feature of the symptom as the 


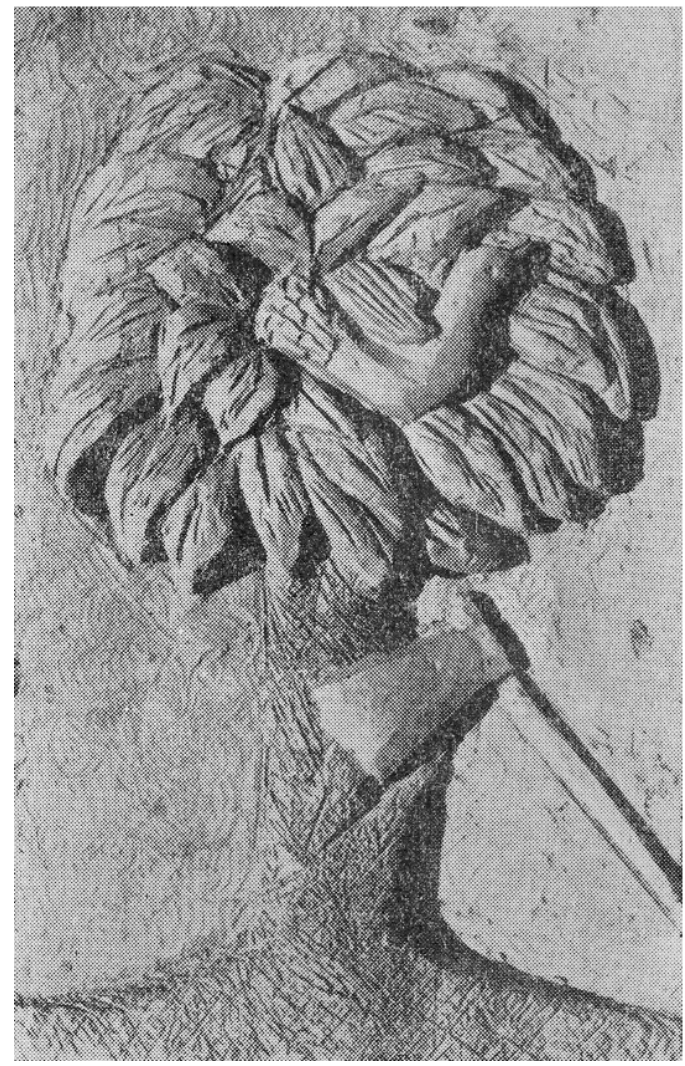

कन्भना

কল্প থেকে শুরু হয়ে গেল কল্পনা মেঘদূতের পাতা থেকে খুব ধূসর একটা মেঘ ভেসে নেল সামনে দিয়ে কেঁপে উঠল চোখের পাতা নড়ে উঠল কল্পদ্রুম পড়তে লাগল সোনা রুুপো ধুলো পড়তে লাগল হীরে কয়ল কাদ। কেঁপে উঠল্ল চোখের পাত। বিহঙ্গ এক উড়তে উড়তেবেহাগ হয়ে গেল একজন কাঠুরে কল্পদ্রুমের কাঠ কার্টছছল

Fig. 2. Kalpana (imagination) -relief work by sculptor Bimal Kundu

kind of perpetual search of a memory that "is inscribed with a force proportional to the mediations punctured or evaded." (537) Lacan had argued that this void can itself be reduced to a kind of object which appears when the imaginary order ceases to fill up the concrete holes in signifying chains with illusions of wholeness. In this fragmented telling, which reappears in a stark encounter with anxiety, the memory of "fact" reappears as narrated "event", where conscious and unconscious, (objective) reality and its interpretation (or subjective fiction) meet (according to Lacan, the symbolic is structured as fiction, with traumas producing holes, gaps, voids and enigmas in the narration of recollected events).

Some of Anjan Sen's poems capture this quality of postcolonial trauma. In many, the combination of myth, history and folklore is felt as a kind of nostalgic encounter, an attempt to fill the void of a postcolonial experience of loss. "Sorrow" captures this sense of trauma, both in its words (translated by Jesse Knutson) and in Diana Magallón's illustration 


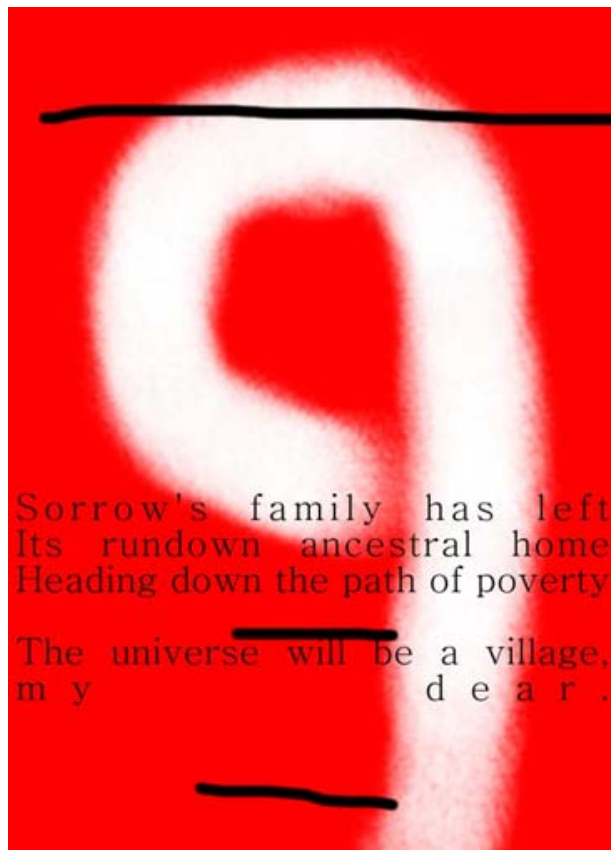

This short poem is about the sadness of migration. Because of globalization, many fertile agricultural lands in India are being taken over by state and industrialists as Special Economic Zones (SEZ). Farmers are not getting enough compensation and they are forced to abandon their houses and their previous lives and head into poverty. Asked by Anjan Sen to comment on "Sorrow", I imagined the white cloud as a kind of letter, a walking stick or a kind of inverted path. Its ghostly quality contrasted strongly with the colour red, frequently associated with blood and passion in many cultures. The two black lines that cut across unevenly conveyed the idea of fragmentation, but also three-dimensionality, just as the black typography of the text. The irony in word "dear" and the mention of McLuhan's famous reference to the world as "Global Village" took on multiple meanings.

In a dialogue with Sen, paradoxically enabled by the virtual environment of the World Wide Web social networks, he advised me to revise the mythical roots of the sound of the cloud and Meghnad in relation to the Ramayana. The idea of sending hidden messages in the form of a cloud made me return to the idea of loss and trauma. It would be interesting to explore to what extend the generic hybridism present in Anjan Sen's poems stage the crossings between rational and irrational experiences, both personal and social. It would be interesting to explore how the trauma of the postcolonial opens up in this dialogue of Sen and his illustrators and critics. In my unstable position of a reader/listener who tries to understand, a critic who tries to speak/write, and a semiotician who tries to discover, I encountered Sen. His desire to be both author and object of interpretation struck me. I see him as attempting to cross not just the limits of author/critic relationships, but also the boundaries of inter-texts, and of intermedial forms of representation. The dialogue between Sen and I, between Sen and his illustrators, readers and critics, seems to be pregnant with a desire to cut-across intersubjective positions and intercultural differences. A dialogue that 
has stretched beyond the borders of a well-known social network and onto these pages, cutting across the artificial divisions between social sciences and humanities, across East and West differences and commonalities, across nostalgia and dreams, helping unveil the shared Ur-topias and community relations of the $21^{\text {st-century. }}$

\section{Acknowledgments}

Anjan Sen is National Tagore Scholar, poet and artist, his works seek a return to the dialogue with others and with nature. Collections of poems in Bengali:

Kathabarta (conversation) 1974

PaathBharatbarsha (reading India) with illustration of Ganesh Pyne ,1981

Tin Bisswe Din Rattri (Days and Nights Over Three worlds) 1988

Goud Bochon (The Gaur Speech) 1989

GoudBochonKothonBisswo (The Gaud Speech)

Bhando Bevando (From earthen pot to universe) 2002

Ghor Bahir (The room the outside) 2007

Chobir Kobita (Poems of the pictorial) 2010

For a complete list of his poetic works, essays, and links to webpages see:

http://www.ucm.es/info/siim/35.php

http://www.ucm.es/info/siim/descargas/AnjanSenBriefCV.pdf

Khandokar Ashraf Hossain (Prof. of English at Dhaka University) is one of the leading literary figures in Bangladesh. He has translated many of Anjan Sen's poems. For more information see

http://en.wikipedia.org/wiki/Khondakar_Ashraf_Hossain

Amlan Das Gupta (Prof of English at Jadapur University, Kolkatta) is a noted scholar of Classical and Biblical Studies, English Renaissance literature and an authority on Miltonic studies in India

http://en.wikipedia.org/wiki/Amlan_Das_Gupta

Udaya Narayayana Sing (Pro-Vice Chancellor, Viswa Bharati University, Linguist, poet, critic) A major linguist, translator, lexicographer \& creative writer who has translated many of Anjan Sen's poems. For more information see

http://www.visva-bharati.ac.in/at_a_glance/unscv.pdf

Edited collections of essays in Bengali Jointly with Anjan Sen:

KobitaarBhaashaa (The Language of Poetry) 1987, 2nd edition 2012

UponyaaserSahityatatwa (The Poetics of Novel) 1989, 2nd edition 2010

Myth ,Sahitya o Samaskriti, (Myth literature and Culture) 1990 2nd edition in press

Eurokendrikata o SilpoSamaskriti (Eurocentrism and Art, Culture) 1992

BaanglaarUttaraadhunikSaahityachinta (The Urraradhunik literary Ideas of Bengal) 2004

Ganesh Pyne has illustrated some of Anjan Sen's poems. Pyne is known for his small tempera paintings, rich in imagery and symbols. He is one of India's foremost contemporary 
painters today. He acknowledges the influence of great painters like Abanindranath Tagore, Hals Rembrandt and Paul Klee. For more information

http://en.wikipedia.org/wiki/Ganesh_Pyne

Bimal Kundu is a sculptor who has illustrated some of Anjan Sen's poems. His profile can be found at

http:// societyofcontemporaryartists.com/artists_details.php?id=16

http://www.aakritiartgallery.com/artist.php?id=348

Diana Magallón is an experimental artist, author of visual poetry books: "Del oiseau et del ogre", "Largos cabellos flotantes", "Pheromones", "Oxygenation" and "Phellipe in wolf" For more info

http:/ / cipollinaaaaa.blogspot.com

\section{References}

Almandoz, Arturo. Ciudad y literatura en la primera industrialización. Caracas: Fundarte, 1993.

Ansay, Pierre, and René Schoonbrodt, eds. Penser la ville. Choix de textes philosophiques. Bruxelles: AAM Éditions, 1989.

Bandopadhyay , Dilip (Ed.) ,Uttar adhunik kabita BEEJ,Calcutta 1993

Bairoch, Paul Economics and World History: Myths and Paradoxes. University of Chicago Press, 1993

Bhalla, Prem P. Hindu Rites, Rituals, Customs \& Traditions Pustak Mahal 2006

Beebee, Thomas O. Nation and Region in Modern American and European Fiction. West Lafayette: Purdue University Press, 2008.

Berger, Morroe. Real and Imagined Worlds: The Novel and Social Science. Cambridge: Harvard University Press, 1977.

Berry, Christopher and Edward L. Glaeser. "The Divergence of Human Capital Levels across Cities." Regional Science 84, 3 (2005): 407-444, available at http://www.nber.org/papers/w11617

Bradbury, Malcolm. "The Cities of Modernism." Modernism. Ed. Malcolm Bradbury and James McFarlane. Harmondsworth: Penguin, 1976.

Brenner, Neil. "The Urban Question as a Scale Question: Reflections on Henri Lefebvre, Urban Theory and the Politics of Scale." International Journal of Urban and Regional Research 24.2 (2000): 361-78.

Brenner, Neil, ed. The Global Cities Reader. London: Routledge, 2005.

Boyer, Christine M. Dreaming the Rational City: The Myth of American City. Massachusets: MIT Press, 1986.

Bridge, Gary, and Sophie Watson, eds. The Blackwell City Reader. Oxford: Blackwell, 2002.

Carr, David M. "The Garden of Eden Story" An Introduction to the Old Testament. John Wiley \& Sons 2011

Chakrabarty, Birenda. ed. Bangla Kabitar Prakritayan, (Craving for legacy of the roots in Bengali Poetry), Granthalay, Kolkata, 1991.

Choay, Françoise. L'Urbanisme, utopies et réalités. Paris: Seuil, 1965.

Collingwood, Roger. G. The Idea of History, Oxford: Oxford UP, 1946. 
Cohn, Dorrit The Distinction of Fiction, Baltimore: The Johns Hopkins University Press, 1999

Collins, Steven Nirvana: Concept, Imagery, Narrative. Cambridge University Press; 2010

Conan, Michel. Middle East Garden Traditions. Dumbarton Oaks 2007

De Certeau, Michel The Writing of History. Trans.Tom Conley. N.Y.: Columbia U.P. 1988

De Certeau, Michel "Walking in the City." The Cultural Studies Reader. Ed. Simon During. London: Routledge, 1994.

De Certeau, Michel. The Practice of Everyday Life. Trans. S. Rendall. Berkeley: University of California Press, 1984.

Debord, Guy. The Society of the Spectacle. Trans. Donald Nicholson-Smith. New York: Zone Books, 1995.

Deleuze, Gilles \& Félix Guattari. Anti-Oedipus: Capitalism and Schizophrenia. Trans. Brian Massumi. Minneapolis: University of Minnesota Press, 1983.

Deleuze, Gilles \& Félix Guattari. A Thousand Plateaus: Capitalism and Schizophrenia. Translated by Brian Massumi. Minneapolis: University ofMinnesota Press, 1987.

Downs, Roger \& David Stea Maps in Minds. New York: Harper \& Row, 1997.

Ejaz Eusoofi (ed.) Special issues on UttarAdhunik poetry, Lyric Journal,Chittagong ,Bangla Desh. 1993,19951999

Eliade, Mircea, The Myth of the Eternal Return: Cosmos and History (trans. Willard R. Trask), Princeton University Press, Princeton, 1971

Eliade, Mircea Images and Symbols: Studies in Religious Symbolism (trans. Philip Mairet), Princeton University Press, Princeton, 1991

Epstein Nord, Deborah. Walking the Victorian Streets: Women, Representation and the City. Ithaca: Cornell University Press, 1995.

Foucault, Michel The Order of Things: An Archaeology of the Human Sciences. Translator Unknown. New York: Vintage Books, 1994 (1966 French version)

---. "Space, Knowledge and Power" In Paul Rabinow (ed.), The Foucault Reader, New York: Pantheon Books, 1984, 239-56

Freud, Sigmund Mourning \& Melancholia, P.F.L. 11. Penguin Books, London, 1917

Gautam Basu and Chiranjib Sur (eds.) “UttarAdhunik” Janapad, 4. 1, Calcutta, 1990

Gilloch, Graeme. Myth and Metropolis: Walter Benjamin and the City. Cambridge: Polity Press, 1996

Gupta ,Amitabha (ed.), UttarAdhunik Kavita Calcuta, 1991

Gupta, Amitabha. Movements in Infinity. D. N. Publications, Kolkata, June 1991.

Gupta, Amitabha UttarAdhunik Chetanar Bhumika, (Introduction to transcendent modern consciousness), Triratna, Kolkata, 1992.

Hamburger, Käte The Logic of Literature, 2nd rev. ed., translated by Merilynn J.Rose,Bloomington: Indiana University Press, 1973 [1968]

Handlin, Oscar, ed. The Historian and the City. Cambridge: MIT Press, 1967.

Hartman, Geoffrey “On Traumatic Knowledge and Literary Studies." New Literary History 26.3 (1995): 537-563.

Henighan, Tom. Natural Space in Literature: Imagination and Environment in Nineteenth and Twentieth Century Fiction and Poetry. Ottawa: Golden Dog Press, 1982..

Hermann, Jacobi, Müller, F. Max. eds. Kalpa Sutra, Jain Sutras Part I, Sacred Books of the East, Vol. 22. Oxford: The Clarendon Press.

Huyssen, Andreas. Present Pasts: Urban Palimpsests and the Politics of Memory. Stanford: Stanford University Press, 2003. 
Jaye, Michael, and Ann C. Watts, eds. Literature and the American Urban Experience. Manchester: Manchester University Press, 1981.

Keunen, Bart, and Bart Eeckhout, eds. Literature and Society: The Function of Literary Sociology in Comparative Literature. Bruxelles: Peter Lang, 2001.

Lacan, Jacques. Le séminaire, livre 10: L'angoisse. Paris: Seuil, 2004.

LaCapra, Dominick History and Criticism. Ithaca/London: Cornell U. P, 1985

LaCapra, Dominick. "Trauma, Absence, Loss." Critical Inquiry 25 (1999): 696-727.

Lash; Scott and Urry, John Economies of Signs and Space. Sage Publications, 1994

Lefebvre, Henri. La Révolution urbaine. Paris: Gallimard, 1970.

Lefebvre, Henri. The Production of Space. Trans. D. Nicholson-Smith. Malden: Blackwell, 1991.

LeGates, Richard, and Frederic Stout, eds. The City Reader. London: Routledge, 2003.

Lehan, Richard. The City in Literature: An Intellectual and Cultural History. Berkeley: University of California Press, 1998.

López-Varela, A. \& Net, Mariana. Real and Virtual Cities. Intertextual and Intermedial Mindscapes. Bucharest: Editura Univers Enciclopedic, 2009

López-Varela, Asunción Embers of Time: A Pluridisciplinary Exploration of the Crisis of Representational Time in Science and Narrative Universidad Complutense 2004

López-Varela, Asunción “Webness Revisited". In A Pleasure of Life in Words: A Festschrift for Angela Downing. Madrid: Universidad Complutense. Eds. Carretero, Marta; Hidalgo Downing, Laura; Lavid, Julia; Martínez Caro, Elena; Neff, JoAnne; Pérez de Ayala, Soledad and Sánchez-Pardo, Esther, Madrid: Editorial Complutense. Vol II, 2006, 513-533

López-Varela, Asunción "La novela gráfica Ciudad de cristal de P. Auster, P. Karasik y D. Mazzucchelli: un estudio de semiótica multimodal" Literatura y Espectáculo. Rafael Alemany Ferrer \& Francisco Chico Rico. Eds. Universitat d'Alacant / Sociedad Española de Literatura General y Comparada, 2012

Lutwack, Leonard. The Role of Place in Literature. Syracuse: Syracuse University Press, 1984.

Lynch, Kevin. The Image of the City. Cambridge: MIT Press, 1960.

Massey, Doreen. ed. A. Space, Place and Gender. Minneapolis: University of Minnesota Press, 1994.

Miles, Malcolm, ed. The City Cultures Reader. London: Routledge, 2000.

Miller, J. Hillis. Topographies. Stanford: Stanford University Press, 1995.

Mumford, Lewis. The City in History: Its Origins, Its Transformations, and Its Prospects. New York: Harcourt, Brace and World, 1961.

Nikam, N.A. Some Concepts of Indian Culture, SIMLA, 1967.

Nitai Jana : Postmodern O Uttar Adhunik Bangla Kabita Parichay (Treatise on Postmodern and Transcendent Bengali Poetry), Banishilpa, Kolkta, 2001.

Palen, John. The Urban World. New York: McGraw-Hill, 2004.

Perry, Ruth. Novel Relations: The Transformation of Kinship in English Literature and Culture, 1748-1818. Cambridge: Cambridge University Press, 2004.

Pike, Burton. The Image of the City in Modern Literature. Princeton: Princeton University Press, 1981.

Porteous, J. Douglas. Landscapes of the Mind: Worlds of Sense and Metaphor. Toronto: University of Toronto Press, 1990. 
Ray, Niharranjan. Idea and Image in Indian Art, New Delhi, 1973

Relph, Edward. Place and Placelessness. London: Pion, 1976.

Ricoeur, Paul; Claude Larre; Raymond, Panikkar; Bettina, Bäumer; Alexis, Kagame; G.E.R. Lloyd; André, Neher; Germano, Pàttaro; Louis, Gardet; Abdelmajid, Meziane;, A.Y. Gourevitch Les cultures et le temps. Paris: Payot, 1975

Said, Edward Orientalism. Pantheon Books 1978.

Seixo, Maria Alzira, ed. Travel Writing and Cultural Memory / Ecriture du voyage et mémoire culturelle. Amsterdam: Rodopi, 2000.

Sennett, Richard. Flesh and Stone: The Body and the City in Western Civilization. London: Faber and Faber, 1996.

Sewell, William H., Jr. "Space in Contentious Politics". In R.N. Aminzade, J.A. Goldstone, D. McAdam, E.J. Perry, W.H. Sewell, S. Tarrow, \& C. Tilly (eds.), Silence and Voice in the Study of Contentious Politics. Cambridge, UK: Cambridge University Press. , 2001, 51-58.

Sharpe, William. Unreal Cities: Urban Figuration in Wordsworth, Baudelaire, Whitman, Eliot, and Williams. Baltimore: Johns Hopkins University Press, 1990

Sternberg, Meir "Telling in Time (II): Chronology,Teleology, Narrativity," Poetics Today 13 (1992): 463-541

Shields, Rob. "A Guide to Urban Representation and What to Do About It: Alternative Traditions of Urban Theory". Re-Presenting the City: Ethnicity, Capital and Culture in the 21st-Century Metropolis. Ed. Anthony D. King. London: Macmillan, 1996. 227-52.

Sutcliffe, Anthony, ed. Metropolis, 1890-1940. London: Mansell, 1984.

Tanushree Bhattacharya (ed.) The UttarAdhunik. Ohio: Wothington, 1996

Tapodhir Bhattacharjee :Adhunikata-Parba theke Parbantar (Modernity through different phases), 2nd enlarged edition, Pustak Bipani, Kolkata, 2004.

Tapodhir Bhattacharjee Kabitar Rupantar (Transformation of Poetry), Sahityaloke, Kolkata, 2004.

Tsai, Hsiu-chih. A Semiotic Reading of City Images in Literature. PhD. Dissertation. Taipei: National Taiwan U., 1997.

Tinkler-Villani, Valeria, ed. Babylon or New Jerusalem? Perceptions of the City in Literature. Amsterdam: Rodopi, 2005.

Tuan, Y.F. Space and Place: The Perspective of Experience. Minneapolis: University of Minnesota Press, 1977.

Walkowitz, Judith R. City of Dreadful Delight: Narratives of Sexual Danger in LateVictorian. London. Chicago: University of Chicago Press, 1992.

Weiss-Sussex, Godela, and Franco Bianchini. Urban Mindscapes of Europe. Amsterdam: Rodopi, 2006.

Williams, Raymond. The Country and the City. London: Chatto and Windus, 1973.

Wilson, Elizabeth. The Sphinx in the City: Urban Life, the Control of Disorder, and Women. Berkeley: University of California Press, 1992.

Wirth-Nesher, Hana. City Codes: Reading the Modern Urban Novel. Cambridge: Cambridge University Press, 1996.

White, Hayden Metahistory: The Historical Imagination in 19-Century Europe, Johns Hopkins UP, 1973, 
104 Social Sciences and Cultural Studies - Issues of Language, Public Opinion, Education and Welfare

Zhang, Yingjin. The City in Modern Chinese Literature and Film. Standord: Standford University Press, 1996. 
(C) 2012 The Author(s). Licensee IntechOpen. This is an open access article distributed under the terms of the Creative Commons Attribution 3.0 License, which permits unrestricted use, distribution, and reproduction in any medium, provided the original work is properly cited. 